CURRENT RESEARCH JOURNAL OF PHILOLOGICAL SCIENCES

(ISSN -2767-3758)

VOLUME 03 ISSUE 01 Pages: 25-30

SJIF IMPACT FACTOR (2021: 5 . 823)

OCLC - 1242423883 METADATA IF - 6.925

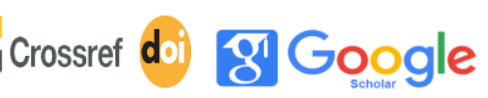

\%

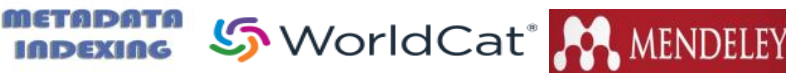

Publisher: Master Journals

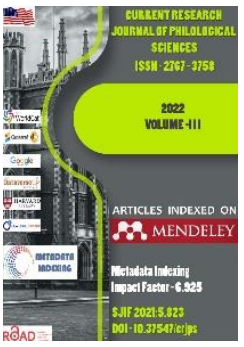

Journal Website: https://masterjournals.

com/index.php/crips

Copyright: Original content from this work may be used under the terms of the creative commons attributes 4.0 licence.
Research Article

\section{A GYNOCRITICAL APPROACH IN FEMINIST RESEARCH}

Submission Date: December 23, 2021, Accepted Date: January 3, 2022, Published Date: January 13, 2022

Crossref doi: https://doi.org/10.37547/philological-crjps-03-01-05

\section{Aziza Zoirova}

Researcher, Karshi State University, Karshi, Uzbekistan

\title{
ABSTRACT
}

While the study of the historical and philosophical foundations of the concept of feminism provides information about its essence, its linguistic study examines the features that are manifested in speech. From a linguistic point of view, all four views are interrelated and have their own impact on the pictorial aspects of the work of art. Since we have conducted our research on the basis of a gynocritical approach, in this chapter we will express our views only on the phenomenon of gynocritics.

\section{KEYWORDS}

Biological model, linguistic, psychonanalytic, cultural, Feminist criticism, Gynocritics.

\section{INTRODUCTION}

While the study of the historical and philosophical foundations of the concept of feminism provides information about its essence, its linguistic study examines the features that are manifested in speech. Feminine speech forms, pragmatic and cognitive features of words and sentences are studied in terms 
CURRENT RESEARCH JOURNAL OF PHILOLOGICAL SCIENCES

(ISSN -2767-3758)

VOLUME 03 ISSUE 01 Pages: 25-30

SJIF IMPACT FACTOR (2021: 5. 823)

OCLC - 1242423883 METADATA IF - 6.925

of the idea of feminism. The penetration of this idea into various branches of science has led to the formation of new terms in linguistics. One such concept is "gynecology," which involves the study of speech features in various literary sources written by women.

\section{THE MAIN RESULTS AND FINDINGS}

Elaine Shouolter used the term "gynocriticisme" in 1970 to refer to women's prose[1]. In 1985, the author's book "New Feminist Criticism" was published. The book covers the work of classic representatives of feminist prose, such as Annette Colodn, Sandra Gilbert, Susan Gubar, Bonnie Zimmerman, Rachel DuPlessy, Alicia Ostreiker, Nancy Miller, Rosalind Coward, and others.

Elaine Shouolter's "Problems of the Feminist Thing"[2] in his article, he outlines 4 models of gynocritics:

1) Biological model;

2) Linguistic;

3) Psychonanalytic;

4) Cultural.

From a linguistic point of view, all four views are interrelated and have their own impact on the pictorial aspects of the work of art. Appreciates the level of realism of women-specific speech. According to many gynecologists, the degree of genuine intimacy of women, especially works written in the feminist spirit, is higher than that of male writers, because by nature women have tried to write openly about what they feel, to express their pain. Different imaginary, imaginary scenes are relatively rare. This feature is due to the fact that female writers initially kept their own diaries, says Nicola Bualo[3]. According to her, the woman started writing by writing down stories about herself in a notebook. As a result, in addition to the autobiographical work, works of art in various genres began to take shape, that is, women's creativity began. It should be noted that most of the works of the great Uzbek women writers Nodirabegim, Uvaysiy, Aydin, Saida Zunnunova, Zulfiya and Zarifa Saidnosirova are dedicated to their families, lifestyles and life in general.

The main purpose of women's literature is the study of works written by writers, one of the new styles is the psychodynamic creativity of women, issues of women's language and style, the problems of women of the protagonists.

Elaine Shouolter also focuses on two main styles in the study of women's literature. These are:

1) Feminist criticism;

2) Gynocritics.

Since we have conducted our research on the basis of a gynocritical approach, in this chapter we will express our views only on the phenomenon of gynocritics.

The scientist makes the following point about gynocritics:

"Ginocriticism - when we free ourselves from the linear and absolute male literary history, we stop writing the woman into the gaps between the lines of male literature and at the same time we focus on the new visible world of female culture proper [4]".

Consequently, as Shouolter points out, only when women's literature is studied objectively from men's literature can there be a truly new view of the female world and a transparent view of the female world.

Women's literature is mainly understood as the work of writers, the image of the heroine, the types of 
CURRENT RESEARCH JOURNAL OF PHILOLOGICAL SCIENCES

(ISSN -2767-3758)

VOLUME 03 ISSUE 01 Pages: 25-30

SJIF IMPACT FACTOR (2021: 5. 823)

OCLC - 1242423883 METADATA IF - 6.925

Crossref
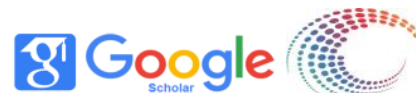
metapata (5) WorldCat

Publisher: Master Journals

women's writing, ie poetry, short stories, autobiographies, memoirs, notebooks. The basic concept is that women writers, writers understand each other, feel, emancipation of women in literature [5] covered ideas.

Women's creativity has been interpreted in various terms in the scientific literature. Sometimes women's literature, women's novels, feminist literature, and so on. As part of the study, we will first consider the fact that this type of work is presented in various dictionaries and encyclopedias.

One of the main features of women's literature is that women writers have created works based on their life experiences, and this view of literature has become a real prose, especially in the nineteenth century. Now one of the leading features of women's prose is that the author is a woman, the protagonist is a woman, the problems are in some ways related to the fate of women [6].

Historian Gerda Lerner points out that the buds of feminism are present in the works of Christina de Pizan, a French writer who created them during the Renaissance, and that theories of "querelle des femmes" emerged in the 15th century[7]. According to historian Karen Oferen, the term "feminism" was first used in 1882 in the French newspaper La citoyenne, when Gubertina Oakler, a member of the women's movement who fought for women's rights in elections, called herself a feminist and always introduced herself in her speeches. The use of the term "feminism" at the first feminist congress in Prij in 1892 led to the widespread popularity of the term. In 1894, the phenomenon of "feminism" gradually began to appear in the political publications of Britain, Spain, Italy, Germany and the United States[8].
It should be noted that early feminists and feminist writers avoided the notion of "feminism" and called themselves "women's advocates" and "women's rights defenders".

Historian Gerda Lerner points out that the buds of feminism are present in the works of Christina de Pizan, a French writer who created them during the Renaissance, and that theories of "querelle des femmes" emerged in the 15th century[9]. According to historian Karen Oferen, the term "feminism" was first used in 1882 in the French newspaper La citoyenne, that is, Gubertina Oakler, a member of the women's movement who fought for women's rights in the election process, calls herself a feminist woman and always describes herself as such in her speeches. The use of the term "feminism" at the first feminist congress in Prij in 1892 led to the widespread use of the term. In 1894, the phenomenon of "feminism" gradually began to appear in the political publications of Britain, Spain, Italy, Germany and the United States[10].

In general, it was Elaine Shoualter who introduced the concept of a "gynocritical approach" in literature, acknowledging that women have unique imagery and ways of imagining. Agneshka Khrinik is another scholar who studies women's literature[11] emphasizing that the origin of the term is associated with autobiographical works, it was Elaine Schoalter who referred to it as "auto-gino-graphic" works, that is, as a concept describing the characteristics and processes inherent in female genetics. A. Khrinik also considers that the trinity of concepts "women's literature feminism - gynecology" is typical of one period. Their linguistic diagnoses serve to form general principles in science. A. Khrinik also mentions that during this period not only female writers, female literary critics, 
CURRENT RESEARCH JOURNAL OF PHILOLOGICAL SCIENCES

(ISSN -2767-3758)

VOLUME 03 ISSUE 01 Pages: 25-30

SJIF IMPACT FACTOR (2021: 5. 823)

OCLC - 1242423883 METADATA IF - 6.925

Crossref
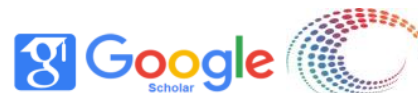

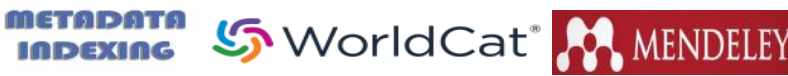

Publisher: Master Journals

but also individual translators engaged in the translation of feminist works began to appear.

Nicola Bualo, a scholar of the history of French literature[12] both link the origins of gynocritical analysis to autobiographical works and reveal their general and specific aspects. Prior to the introduction of the gynocritical approach to science, works written by women were referred to in a variety of terms, including autogynography, autography, autoethnography, oughttobiography, and prison narratives. However, literary critics, especially feminists, have rejected all of these terms, arguing that gynecology is the only approach that can perfectly convey the style of the female writer, the female protagonist, the female critic, and the female translator.

Due to the introduction of the gynocritical approach in the study of women's literature, special sites for thesaurus, corpus and glossaries specific to women's speech have been created on modern Internet networks. In contrast to the hymns of strong hatred or, conversely, love in men's literature, gynocritics do not create the principles of analysis specific to women's literature and do not conform to men's style, shows that the female style has its own characteristics. Gynocritical analysis, apart from classical analysis, proves that the female writer has a specific direction and acquires new cultural perspectives by abandoning any critical, exaggerated images in men's literature[13].

E.Shoualter's next "Towards a Feminist Poetics Showalter" traces the history of women's literature, concludes that there are three phases in this direction, and they are explained as follows:

The Feminine: In the Feminine Period (1840 - 1880) "women wrote to align themselves with the intellectual male culture and internalized its claims of femininity" (New, 137).

The feminist phase $(1880$ - 1920) was characterized by women's writing that protested against men's standards and values and advocated for women's rights and values, including the demand for autonomy.

Female: Female Phase (1920); is one of the independent discoveries. Showalter says: "Women reject both imitation and protesting the two forms of addiction and instead look to the female experience as a source of autonomous art, extending feminist cultural analysis to literary forms and methods[14]".

Russian gynecologist, linguist and translator S.A. Bakaeva[15] also gynocritically analyzing J. de Stal's Dolphin, translated from French into Russian, with a special focus on a woman's state of mind and attitudes in different situations. Although the work was written before the formation of the feminist movement, it is one of the first examples of this trend. Commenting on the unique style of depiction in the work, SA Bakaeva commented: "The analysis is carried out on the basis of modern theories of ginocritics, in particular," double voice ", which allow interpreting the text of the selected novel from the point of view of feminist concepts. Having chosen the epistolary genre as a form of narration, which presupposes the presence of an " omniscient reader " (lecteur omniscient), choosing a special theme, and also titling the novel with the name of the main character, de Stael approved a special form of literary embodiment of the gender theme, which later theorists of feminism will form the basis of the concept of "women writing"[16]".

Through the above sentence "double voice" S.A. Bakaeva simultaneously reflects the opinion of a woman as a writer and the opinion of a mother (woman, wife, sister, mistress) who performs her 
CURRENT RESEARCH JOURNAL OF PHILOLOGICAL SCIENCES

(ISSN -2767-3758)

VOLUME 03 ISSUE 01 Pages: 25-30

SJIF IMPACT FACTOR (2021: 5. 823)

OCLC - 1242423883 METADATA IF - 6.925

Crossref $d$
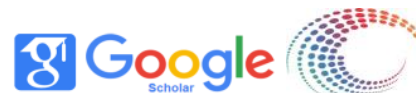

metaparn (5) WorldCat

Publisher: Master Journals

normal role in society. The fact that the play shows not only the system of events, but also the attitude of society towards women has caused a lot of discussion.

According to A. Stobierska, it is only through women's literature that we can understand the real differences in the behavior of members of both sexes. This Polish scholar, who has studied the history of the formation of special attention to the image of women, makes the following comments in the course of research on feminism in France: "To rediscover this story, which is the basis of the individual and collective identity of women, we must refer to the myths of the origin and reread them, and even redefine them from a female point of view. Indeed, my thesis aims to study the rewriting of myths proposed by women, myths that evoke our spiritual mothers and the relationships they formed with their daughters[17]". That is, the existence of an individual and collective character of a woman, the relationship between mother and daughter, the study of the spiritual and spiritual world of women in general requires the reference to longstanding legends.

\section{CONCLUSION}

Thus, the study of not only works on feminism, but also the sources specific to all women's creativity from different angles forms the basis of the gynocritical approach, which is mainly reflected in feminist sources. However, not all women's works can be feminist works either, yet some of their features can be analyzed on the basis of a gynocritical approach. We have taken a critical approach to the analysis of the works we have selected for research, namely George Sant's Indiana, Jermaine de Stalin's Delfina and Corina. The fact that the translators of the above-mentioned works are both female and male helps us to clarify issues such as the degree of conformity of the original, the quality of translation and the writer, the work and the translator's style, psyche when translating the works of female writers. This served to reveal more clearly the method and scientific significance of the research.

\section{REFERENCES}

1. Showalter E. The Double Standard and the Feminine Nobel. In a Literature of their own: British Women novelist from Bronte to Lessing. Princeton University Press 1977. -P. 296.

2. Шовалтер, Е. (1996). Феміністична критика у пущі. М. Зубрицька (Ред.), Слово. Знак. Дискурс: Антологія світової літературнокритичної думки XX ст. (с. 510-535). Львів: Літопис.

3. Nicolas Boileau. Un genre à part : l'autobiographie et la gynocritique, Rennes, 2008. 289-304 p.

4. Elaine Showalter. Towards a Feminist Poetics. New York: Pantheon Books, 1985. -P125.

5. Эмансипация - (лот) жабр зулм, қарамлик, тутқунлик, турли бидъатлардан қутилиш эмас, хотин қизлар Эмансипацияси. Qomus Info. Онлайн Энциклопедия.

6. Мухаммедова Х. Танқидий реализм адабиётида аёллар насрининг тараққиёт босқичлари. -Б. 236.

7. Cristina de Pisan

8. Title L. Encyclopedia of Feminism. New: York Arrow Books, 1986.

9. CKristina de Pisan

10. Title L. Encyclopedia of Feminism. New: York Arrow Books, 1986.

11. Хрынык А. Творчество Марины Цветаевой в контексте гендерных исследований, Познан, 2017. - C. 81.

12. Nicolas Boileau. Un genre à part : l'autobiographie et la gynocritique, Rennes, 2008. 289-304 p. 
CURRENT RESEARCH JOURNAL OF PHILOLOGICAL SCIENCES

(ISSN -2767-3758)

VOLUME 03 ISSUE 01 Pages: 25-30

SJIF IMPACT FACTOR (2021: 5 . 823)

OCLC - 1242423883 METADATA IF - 6.925

13. http://ru.knowledgr.com

14. http://ru.knowledgr.com

15. Бакаева С.А. Женщина и общество:

феминистские идеи в романе мадам де

Сталь «Дельфина». Филологические науки в мГИмо. 2019;18(2):69-76.

https://doi.org/10.24833/2410-2423-2019-2-18-

69-76

16. Бакаева С.А. Женщина и общество: феминистские идеи в романе мадам де Сталь «Дельфина». Филологические науки в мгимо. 2019;18(2):69-76. https://doi.org/10.24833/2410-2423-2019-2-18-

69-76

17. Agnieska STOBIERSKA. Construire la généalogie féminine à travers la réécriture des mythes dans la littérature féminine contemporaine française et polonaise, Nice, 2005. P. 8. 